movements in their normal habitat of the forests. They apparently are not shy or particularly timid but would normally fly at the approach of man or machine. Considering the normal reflexes of ibirds of this size and their usually rapid actions it would seem that there must be some reason for their inability to escape collision with the modern day car or truck on the highway. One clue might be their fatal fascination for the muddy, briny water around which they watered. Would not snow suffice for a thirstquencher? Were their usual supplies of water inaccessible or frozen? It might be that the chemicals used to melt snow on the highways have a particular effect on these birdis.

Editor's Note-Mr. Baker's suggestion that the birds were attracted to the road by the salt used on it to melt the snow undoubtedly answers the question of why such large flocks were encountered and killed on the Maine highway. It has been pointed out by ornithologists that "some winter finches seem to crave salt especially, perhaps because of mineral deficiencies in their customary diet" (G. J. Wallace. 1955. An introduction to ornithology. Macmillan Co., New York, p. 319). In this connection Wing might also be quoted (L. W. Wing. 1956. Natural history of birds. Ronald Press Co., N.Y., p. 92) because he mentions some of the species that seem particularly attracted: "Field observations indicate that Doves, Crossbills, Pine Grosbeaks, Purple Finches, Evening Grosbeaks, and other species regularly resort to 'salt licks.' Analysis of several such licks in the West shows that the water-soluble salts present include chlorides, sulphates, hydrocarbonates, and carbonates of sodium. Some magnesium and calcium salts may also be present."

\title{
SOME FEEDING HABITS OF THE RUBY-THROATED HUMMINGBIRD
}

\author{
by Alvin Binnie, Regina
}

Last summer (1964) I had the good fortune to be able to observe closely some feeding habits and preferences of the Ruby-throated Hummingbird. The ability of these helicopters of the bird world to seek out and take advantage of the drilling of the Yellowbellied Sapsucker came as a distinct surprise to me.

I chanced upon this association while seeking additional water supplies for a cattle herd in the Qu'Appelle Valley, north of Regina. It was late July and the morning was very hot. I climbed a ledge protruding from the southern slope to investigate a tiny itrickle of water. Pausing to rest in the welcome shade of a grove of poplars, I noticed a male sapsucker vigorously drilling alternately in a white birch and a white poplar. While thus engaged he was closely pursued by two juveniles, clamoring to be fed. I had barely time to digest the fact that Yellow-bellied Sapsuckers nested in the area (four miles east of No. 6 Highway) when a pair of Ruby- throated Hummingbirds appeared on the scene. They moved from hole to hole gathering sap from both poplar and birch. Interestingly enough, a similar observation from this very area in the Qu'Appelle has since been reported to me. About two miles west of No. $6 \mathrm{Highway,} \mathrm{and} \mathrm{hence} \mathrm{only} \mathrm{five}$ miles from my site, on June 24, 1964, R. W. Nero and G. F. Ledingham watched adult male and female Rubythroats feeding in mid-afternoon at fresh sapsucker holes in an aspen on the forested south slope of the valley.

The opportunity to observe this feeding procedure for the second time came to me on August 5 at Moose Mountain Provincial Park. On this occasion the sapsuckers were drilling only in white birch and only where some thoughtless person had stripped away the outer bark. Several trees were completely ringed with holes and nowhere were the holes more than two inches apart. We actually saw a pair of adult hummers feeding on the 
drilled side of a birch while a juvenile sapsucker was hammering out more holes on the opposite side.

From July 28, when the first Rubythroat arrived in our garden five miles east of Regina, throughout August and until September 11 we were able to observe closely the feeding preferences of from one to three of these birds. Both our garden and our neighbour's contained extensive flower beds. The menu set before the hummers was varied and their favorite food was served from a multitude of coloured cups. Our guests ware free to choose from any the following: petunias, snapdragons, hollyhocks, geraniums and gladoli. Careful day to day observations proved that the No. 1 choice was the petunia and in this species a definite colour pattern was followed. ${ }^{2}$ The red flowers were always visited first, the purple ones second. In the process of working over a petunia bed, the hummers would occasionally stop at a white blossom but were never observed feeding from one. Hollyhocks appeared to be second best, with geraniums also well ratel. Snapdragons and gladioli were visited intermittently.

While the weather was very warm we noted that the Ruby-throats confined most of their feeding to very early in the morning and from early evening until dark. When the weather became cooler they searched for food throughout the day.

${ }^{1}$ A. C. Bent in his Life histories of North American woodpeckers (1939) described the association of sapsuckers and Ruby-throated Hummingbirds which are attracted to the sap flowing from holes drilled by the sapsuckers, and P. A. Taverner in his Birds of Canada (1949) also refers to the fact that many small birds, including hummingbirds, are attracted to the sweet oozing sap. [Ed.]

${ }^{2}$ The question of colour preference is also raised by Bent (1940. Life histories of North American cuckoos, goatsuckers, hummingbirds and their allies.) $\mathrm{He}$ writes: "Hummingbirds have been seen so frequently hovering before the brilliant red flowers in our gardens - trumpet vines clambering over the porch, salvias gleaming scarlet in the flower beds - that it has been assumed the birds have a pref- erence for the color red. However, the extensive investigations of Andrew L. Pickens (1930) bring out the fact that it is brightness of color - its conspicuousness against the background - that draws the hummingbird to a flower." Pickens has proposed, for example, that green flowers that are too inconspicuous among foliage should have value in certain contrasting desert backgrounds, or on the sere dry-season prairies. "While no green Hummingbird flowers are known in the East," he says, "Nicotiana paniculata one of the greenest large flowers I know, is much frequented in the west during the dry season at least." He concludes that "complete lists would probably show red, the sharpest contrast to green, a favorite everywhere, with orange in some favor in tree-shaded regions and a neglected color like green rising in sun-browned territory." [Ed.]

\section{CASPIAN TERN AGAIN SIGHTED AT REGINA}

by Robert W. Nero

On July 10, 1964, while conducting a university class in field ornithology, I observed a Caspian Tern at the Regina Waterfowl Park. Members of a small colony of Common Terns were harassing the intruder which was hovering and flying about their nest sites on "tern island." On at least one occasion the Caspian Tern gave a low, harsh cry. A few minutes after sighting the bird some Ring-billed Gulls flew over the marsh heading northwest and the tern, which suddenly disappeared, was presumed to have flown off with them.

The Caspian Tern was reported seen in the same area on July 22-23, 1960, by F. Brazier (1960. Caspian Tern at Regina. Blue Jay, 18:161). There is, so far as I am aware, only one other published record of this tern for southern Saskatchewan; H. H. Mitchell, as pointed out by Dr. Stuart Houston (1956. The Caspian Tern in Saskatchewan - with first nesting record. Blue Jay, 14:116-117), took a specimen at old Wives Lake on June 28, 1927. The nearest nesting locality is that discovered by Houston at Dore Lake, some 300 miles northwest of Regina. 